\title{
Design Study of Gas Cooled Fast Reactor (GFR) with Uranium Plutonium Carbide (UC-PuC) as Fuel with Addition Protactinium (Pa- 231)
}

\author{
Alvi Nur Sabrina ${ }^{1, a}$, Arindi Kumala Sari ${ }^{1}$, Laela Nur Janah ${ }^{1}$, and M. Rizqi \\ Maulana $^{1}$ \\ ${ }^{1}$ Department of Physics, Faculty of Mathematics and Natural Sciencs, University of Jember, \\ Jalan Kalimantan No 37 Jember 68121, Indonesia \\ asabrinaalvi31@gmail.com
}

\begin{abstract}
Analysis performance of uranium plutonium carbide (UC-PuC) as fuel in gas cooled fast reactor (GFR) with addition of protactinium as a burnable poisons has been done. Neutronic analysis in this research was carried out using the SRAC code from JAERI with a nuclear library based on JENDL 4.0. The calculation is carried out by two steps, the first step is the PIJ calculation which calculates the fuel cell and the second step is the CITATION calculation which calculates the various configurations of the reactor core. The first calculation determines the k-eff value in a homogeneous core configuration. The results obtained show that the percentage of $10 \%$ is the sloping result with a $\mathrm{k}$-eff value of $1 \%$. The second calculation determines the $\mathrm{k}$-eff value in the heterogeneous core configuration. The results obtained indicate that the fuel variation $8 \%-10 \%-12 \%$ is the most critical percentage with a peak power density value of less than $100 \mathrm{Watt} / \mathrm{cc}$. Furthermore, the addition of protactinium with a variation of $0 \%$ to $5 \%$. At a protactinium $4 \%$ percentage and $63 \%$ fuel fraction, the excess reactivity value is $1.02 \%$ or close to $1 \%$ which indicates that the reactor is in a critical condition.
\end{abstract}

Keywords: GFR, Uranium Plutonium Carbide, Protactinium

\section{Introduction}

Generation IV reactors consist of six types of reactors, i.e. Gas Cooled Fast Reactor (GFR), Lead Cooled Fast Reactor (LFR), Molten Salt Reactor (MSR), Sodium Cooled Fast Reactor (SFR), Supercritical Water Cooled Reactor (SCWR), and Very High Temperature Reactor (VHTR) [1]. One of the advantages of generation IV reactors is the inheren safety, sustainability, non-proliferation, and is more economical than other power plants. Research on GFR has been done previously by Syarifah et al. Research on the design study of 200MWth gas cooled fast reactor with nitride (UN-PuN) fuel long life without refueling using PIJ dan CITATION calculation with data library JENDL 3.2 has been carried out, optimum result k-eff value is 1.10142 with excess reactivity value $1.403 \%$ [2]. Other research has also been carried out regarding neutronic analysis of thorium nitide (Th, U233) $\mathrm{N}$ fuel for 500MWth gas cooled fast reactor (GFR) long life without refueling with PIJ dan CITAION calculation and data library JENDL 4.0, the resulting k-eff value is 1,01229 with excess reactivity value $1.21 \%$ [3]. And other studies on GFR with UN-PuN fuel have been carried out by Syarifah [4-7]. Design study GFR 300 MWth was carried out with variations fuel fraction with uranium plutonium carbide and variations addition of protactinium as a burnuble poison. 


\section{Theoretical Background}

Nuclear power plant (PLTN) is an alternative energy that can be used to support the world's electricity needs. Nuclear power is considered the best source of choice for electricity generation [8]. Further development of nuclear power is needed to meet future energy demands on demand. Designing a nuclear system needs to emphasize a highest level of safety. Generation IV reactors include a future nuclear system which has four goals, namely economy, sustainability, safety, reliability and proliferation. One of the generation IV reactors is the GFR, which is a helium gas cooled fast reactor using the fast neutron spectrum. The function of the cooling gas is an inert chemical capable of operating at high temperatures without corrosion and toxicity and a single phase that eliminates boiling [9].

The reaction that occurs in the reactor is called a nuclear reaction, where the nuclear reaction is the collision of two nuclei or two particles which produce a nucleus or particle that is different from its origin [5]. Nuclear reactors in the process require a fuel that is used to produce nuclear energy. Fuel is divided into two, namely fisil material and fertil material [10]. The fuel used is plutonium uranium carbide with the addition of protactinium 231 as a burnuble poison. Protactinium has a large catch section and is used to reduce excess reactivity at the start of combustion. The use of protactinium is also used to reduce the world's waste fuel [11]. This research was conducted by varying the fuel fraction from $60 \%$ to $65 \%$ and varying the protactinium $0 \%$ to $5 \%$.

\section{Materials and Methods}

Determination of fuel, cladding, and coolant in the reactor can affect the safety factor and reactor economy. In this study, the pin design geometry uses the hexagonal cell geometry as shown in Figure 1. The geometry is divided into six regions, where the first three areas are the fuel area, the next one is the cladding area, and the next two are the coolant areas. The active core diameter is $240 \mathrm{~cm}$ and the active core height is $100 \mathrm{~cm}$. Table 1 shows the reactor design parameters that have been designed.

Table 1. Reactor design parameter

\begin{tabular}{cc}
\hline Design parameters & Specification \\
\hline Power & 300 MWth \\
Fuel material & Uranium Plutonium Carbide (UC) \\
Cladding material & Silicon Carbide $(\mathrm{SiC})$ \\
Coolant material & Helium (He) \\
Fuel fraction & $60 \%-65 \%$ \\
Cladding fraction & $10 \%$ \\
Coolant fraction & $25 \%-30 \%$ \\
Active core diameter & $240 \mathrm{~cm}$ \\
Active core height & $100 \mathrm{~cm}$ \\
Reflector axial \& radial width & $50 \mathrm{~cm}$ \\
Burn-up time & 20 years \\
\hline
\end{tabular}




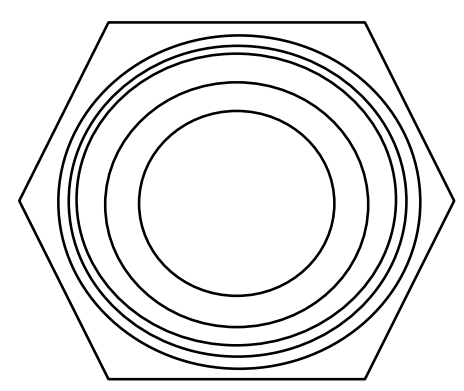

Figure 1. Cell geometry

In this study the calculations were carried out using the SRAC Code. SRAC (Standard Reactor Analysis Code) is a code developed by JAERI (Japan Atomic Energy Agency). The SRAC is designed for neutronic calculations of various types of reactors. The nuclear data library used is JENDL 4.0 which is the latest nuclear database developed by Japan. SRAC includes effective microscopic and macroscopic production, and static cell and core calculations including burn-up analysis. First, the PIJ calculation which calculates fuel cells in the form of hexagonal cells using the Collision probability methods (CPM) method. In the PIJ calculation we get the k-inf value, burn-up analysis and others. After that, proceed with the calculation of the reactor core using CITATION calculations with various core configurations [12].

\section{Results and Discussion}

Analysis performance of uranium plutonium carbide (UC-PuC) as fuel in gas cooled fast reactor (GFR) with addition of protactinium as a burnuble poisons has been done. The first step in the calculation is to determine the k-eff value based on the variation of homogeneous and heterogeneous fuels with a fuel fraction of $60 \%$, cladding $10 \%$, and coolant $30 \%$. Figure 2 . is a graph of the k-eff value in a homogeneous core configuration with a fuel value variation of $5 \%$ to $15 \%$. The graph of the k-eff value in the homogeneous core configuration shows that $10 \%$ fuel variation is the most sloping result, with a delta k-eff value of 0.007638 or equal to $1 \%$. 


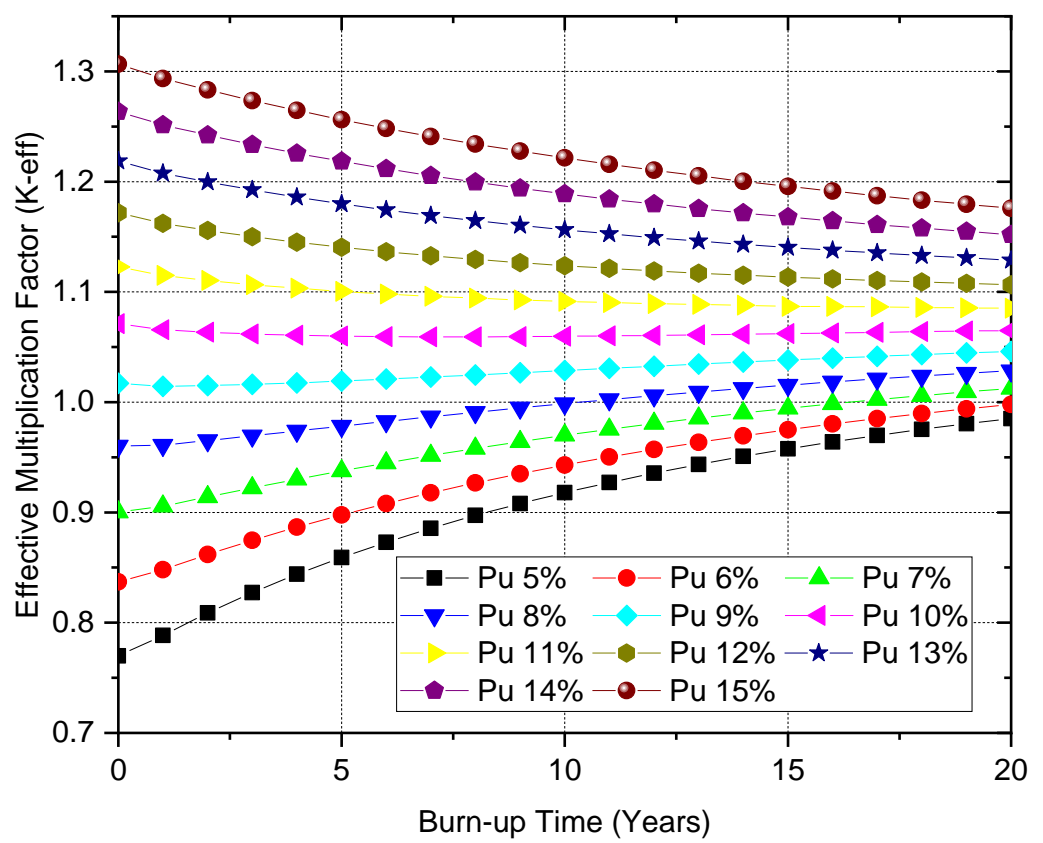

Figure 2. The k-eff value in a homogeneous core configuration

The next calculation uses a heterogeneous core configuration, where the fuel used has three variations in value with an average of $10 \%$. Figure 3 . is the result of calculating the k-eff value obtained in the heterogeneous core configuration. Fuel variation with a value of $8 \%-10 \%-12 \%$ is the variation that shows the most critical results, with a peak power density value less than 100 watt/cc. The power distribution to the radial direction of the mesh in the homogeneous and heterogeneous core configurations in the reactor core can be seen in Figure 4.

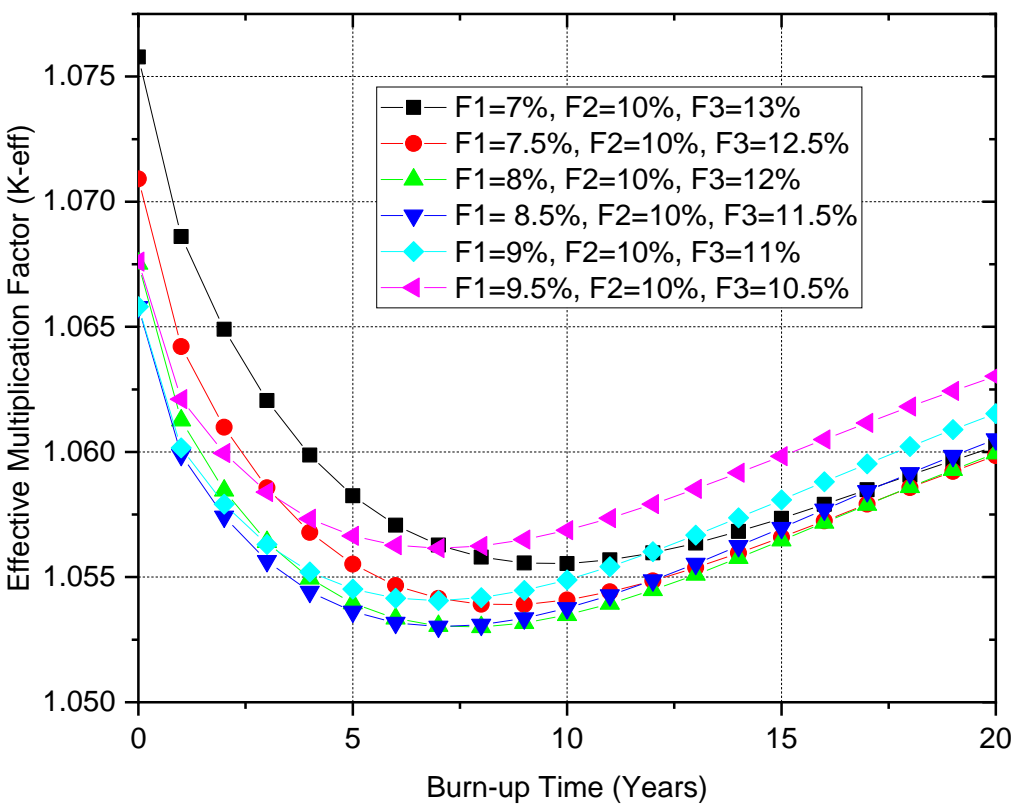

Figure 3. The k-eff value in a heterogeneous core configuration 


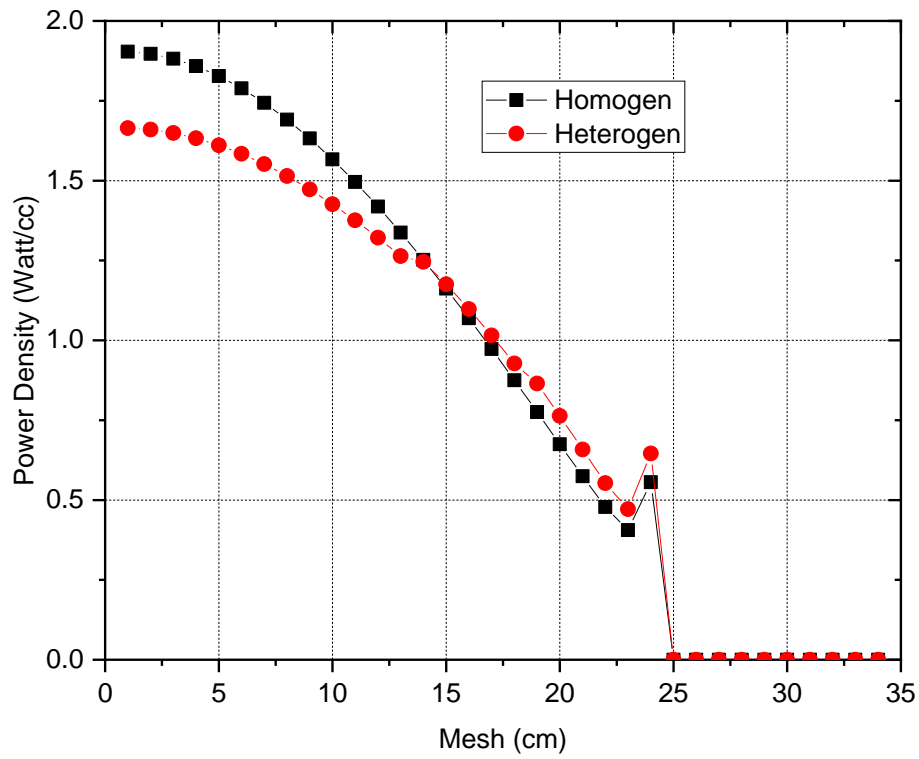

Figure 4. The power distribution to the radial direction of the mesh in the homogeneous and heterogeneous core configurations

Figure 5. describes the effect of the addition of protactinium (Pa-231) on the k-eff value. The addition of $0 \%$ to $5 \%$ protactinium causes a decrease in the k-eff value during combustion. The variation of protactinium addition of $4 \%$ showed the most effective results, with a delta k-eff value of 0.009931 (k-eff 1\%).

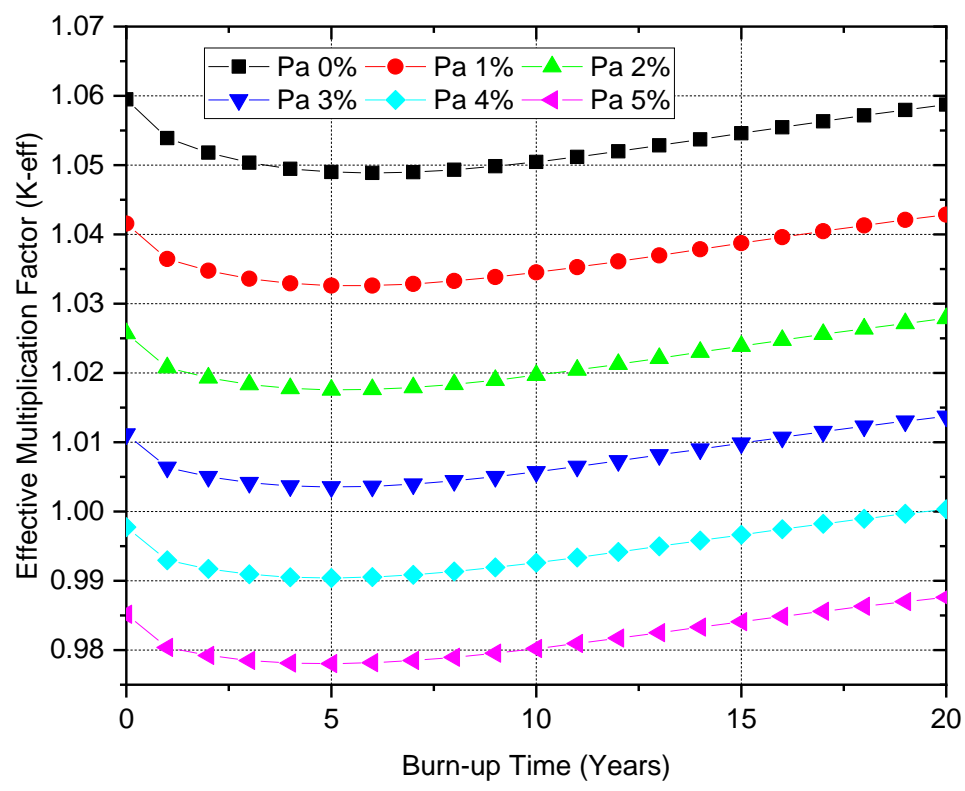

Figure 5. The k-eff value with the addition of $\mathrm{Pa}(0 \%-5 \%)$ 
Figure 6 explains the effect of variations in the fuel fraction from $60 \%$ to $65 \%$, where the variation in the fuel fraction of $63 \%$ shows the k-eff increased significantly with an average value of k-eff $\sim 1$ and the maximum excess reactivity value obtained is $1,02 \%$. The final result in Figure 7 shows that the calculation of the k-eff value at the variation of the $63 \%$ fuel fraction with the addition of $\mathrm{Pa}-2314 \%$, results in the reactor with the most critical condition with a maximum excess reactivity value of $1.02 \%$.

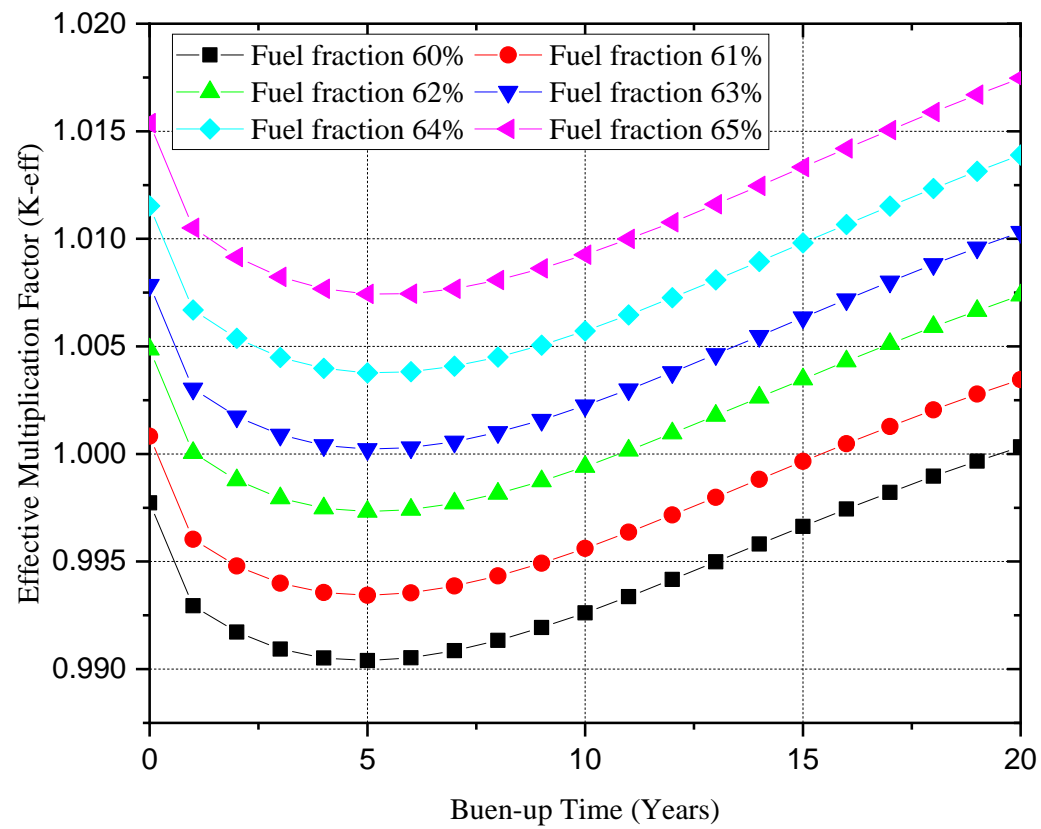

Figure 6. The k-eff value ( $\mathrm{Pa} 4 \%)$ with variations fuel fractions $(60 \%-65 \%)$

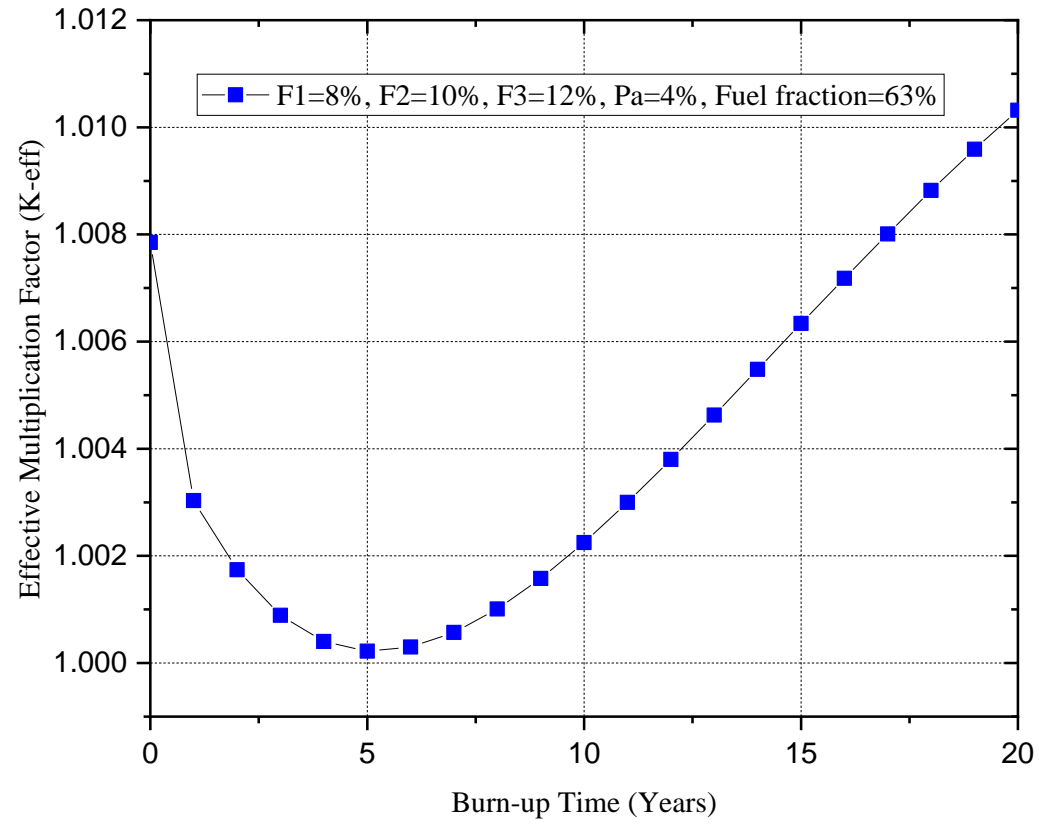

Figure 7. Optimization results design k-eff value 


\section{Conclusions}

Analysis performance of uranium plutonium carbide (UC-PuC) as fuel in gas cooled fast reactor (GFR) with addition of protactinium as a burnuble poisons has been done. The k-eff value which indicates the criticality level of the reactor, can be reduced during the combustion period to reach a critical state in the reactor by adding $\mathrm{Pa}-2310 \%$ to $5 \%$ and varying the fuel fraction from $60 \%$ to $65 \%$ to produce the k-eff value. which indicates the reactor is in a critical state (k-eff 1). The results obtained show that, the addition of protactinium $4 \%$ with a fuel fraction of $63 \%$ results in a k-eff $\sim 1$ value and produces a maximum excess reactivity of $1.02 \%$.

\section{Acknowledgements}

The authors gratefully acknowledge the support of Nuclear Team for the enthusiastic and helped in conducting the reasearch and would like to thank Dr. Ratna Dewi Syarifah, S.Pd., M.Si., for lots of guidance and helpful discussion.

\section{References}

[1] GIF (The Generation IV International Forum), 2014, Technology Roadmap Update for Generation IV Nuclear Energy System, the OECD Nuclear Energy Agency.

[2] R. D. Syarifah, Y. Yulianto, Z. Su'ud, K. Basar, and D. Irwanto, 2016, Design Study of 200MWth Gas Cooled Fast Reactor with Nitride (UN-PuN) Fuel Long Life without Refueling, In MATEC Web of Conferences (EDP Sciences), volume 82, page 03008.

[3] R. D. Syarifah, Z. Su'ud, K. Basar, and D. Irwanto, 2017, Fuel Fraction Analysis of 500 MWth Gas Cooled Fast Reactor with Nitride (UN-PuN) Fuel without Refueling, In Journal of Physics: Conference Series, IOP Publishing, volume 799, page 012022.

[4] R. D. Syarifah, Z. Su'ud, K. Basar, and D. Irwanto, 2016, The Prospect of Uranium Nitride (UN-PuN) Fuel for 25-100MWe Gas Cooled Fast Reactor Long Life without Refueling, In Journal of Physics: Conference Series, IOP Publishing, volume 776 page 012103.

[5] R. D. Syarifah, Z. Su'ud, K. Basar, and D. Irwanto, 2017, Comparative Study on Various Geometrical Core Design of 300 MWth Gas Cooled Fast Reactor with UN-PuN Fuel Longlife without Refueling, In Journal of Physics: Conference Series, IOP Publishing, volume 877 page 012064

[6] R. D. Syarifah, Z. Su'ud, K. Basar, and N. Kurniasih, 2018, Design Study of 600 MWt Long Life Modular Gas Cooled Fast Reactors, In Journal of Physics: Conference Series, IOP Publishing, volume 1090 page 012021.

[7] R. D. Syarifah, Z. Su'ud, K. Basar, and D. Irwanto, 2018, Neutronic Analysis of UN-PuN Fuel use FI-ITB-CHI Code for 500MWth GFR Long Life without Refueling, In Journal of Physics: Conference Series, IOP Publishing, volume 1090 page 012033. 
[8] GIF (The Generation IV International Forum), 2002, A technology Roadmap for Generation IV Nuclear Energy System, U.S DOE Nuclear Energy Research Advisory Committee.

[9] Z. Alatas, S. Hidayati, M. Akhadi, M. Purba, and M. Sofyatiningrum, 2015, Buku Pintar Nuklir, Adi Asmara.

[10] J. J. Duderstadt, and L. J. Hamilton, 1976, Nuclear Reactor Analysis. JohnWiley \& Sons, Inc., New York.

[11] M.N Subkhi, Z. Su'ud, and A. Waris, 2013, Netronic Design of Small Long-Life PWR using Thorium Cycle, In Advanced Materials Research, Trans Tech Publications Ltd, volume 772, page 524-529.

[12] K. Okumura, T. Kugo, K. Kaneko, and K. Tsuchihashi, 2002, SRAC (Ver. 2002): The Comprehensive Neutronics Calculation Code System. Japan Atomic Energy Research Institute, Tokai-mura, Japan. 